\title{
Water Environments: Anthropogenic Pressures and Ecosystem Changes in the Atlantic Drainage Basins of Brazil
}

Author(s): Marcia Marques, Monica F. da Costa, Maria Irles de O. Mayorga, and Patrícia R. C. Pinheiro Source: AMBIO: A Journal of the Human Environment, 33(1):68-77. 2004.

Published By: Royal Swedish Academy of Sciences

DOI: http://dx.doi.org/10.1579/0044-7447-33.1.68

URL: http://www.bioone.org/doi/full/10.1579/0044-7447-33.1.68

BioOne (www.bioone.org) is a nonprofit, online aggregation of core research in the biological, ecological, and environmental sciences. BioOne provides a sustainable online platform for over 170 journals and books published by nonprofit societies, associations, museums, institutions, and presses.

Your use of this PDF, the BioOne Web site, and all posted and associated content indicates your acceptance of BioOne's Terms of Use, available at www.bioone.org/page/terms of use.

Usage of BioOne content is strictly limited to personal, educational, and non-commercial use. Commercial inquiries or rights and permissions requests should be directed to the individual publisher as copyright holder. 


\section{Water Environments: Anthropogenic Pressures and Ecosystem Changes in the Atlantic Drainage Basins of Brazil}

Densely occupied drainage basins and coastal zones in developing countries that are facing economic growth are likely to suffer from moderate to severe environmental impacts regarding different issues. The catchment basins draining towards the Atlantic coast from northeastern to southern Brazil include a wide range of climatic zones and diverse ecosystems. Within its borders lies the Atlantic rain forest, significant extensions of semiarid thorn forests (caatinga), vast tree and scrub woodlands (cerrado) and most of the $6670 \mathrm{~km}$ of the Brazilian coast and its marine ecosystems. In recent decades, human activities have increasingly advanced over these natural resources. Littoralization has imposed a burden on coastal habitats and communities. Most of the native vegetation of the cerrado and caatinga was removed and only $7 \%$ of the original Atlantic rainforest still exists. Estuaries, bays and coastal lagoons have been irreversibly damaged. Land uses, damming and water diversion have become the major driving forces for habitat loss and aquatic ecosystem modification. Regardless of the contrast between the drought-affected northeastern Brazil and the much more prosperous and industrialized southeastern/southern Brazil, the impacts on habitat and communities were found equally severe in both cases. Attempts to halt environmental degradation have not been effective. Instead of focusing on natural resources separately, it is suggested that more integrated environmental policies that focus on aquatic ecosystems integrity are introduced.

\section{INTRODUCTION}

The Atlantic coast of South America presents low topographic relief bordering a broad continental shelf typically with few large $\left(>200000 \mathrm{~km}^{2}\right)$ drainage basins, such as Amazon, Tocantins, Parnaiba, São Francisco, Paraguay, and Paraná rivers and several medium $\left(10000-200000 \mathrm{~km}^{2}\right)$ and small-sized $\left(<10000 \mathrm{~km}^{2}\right)$ drainage basins with variable water and sediment discharges, mostly determined by climate (1). The majority of the population and economic activities of South America are on the Atlantic border. Two essentially Brazilian hydrographical areas assessed by the project Global International Waters Assessment (GIWA), UNEP/GEF, drain towards the Atlantic coast: $i$ ) the area formed by the South/Southeast and East Atlantic basins plus São Francisco River basin (respectively, 80-88; 50-59, and 40-49 in Fig. 1, named by GIWA, Brazil Current); and ii) the area formed by the western and eastern Northeast Atlantic basins plus the Parnaíba River basin (30-39 in Fig. 1, named by GIWA, Brazilian Northeast). Although only $2.3 \%$ of the Brazil Current catchment's area is outside Brazilian territory (the Uruguayan portion of the bi-national Mirim Lagoon basin), important basins shared by more

Figure 1. Western Northeast Atlantic basins (basins 31-33), Parnaíba River basin (basin 34) and Eastern Northeast Atlantic basins (basins 35-39). São Francisco River basin (sub-basins 40-49), East Atlantic basins (basins 50-59) and South/Southeast Atlantic basins (basins 50-59) and South/Southeas Atlantic basins (basins $80-88$ ). East basins of Uruguay (basins 89). Large Marine Ecosystems (2) LME-15, LME-16 and LME-17 (South, East and North Brazil Shelf, respectively).

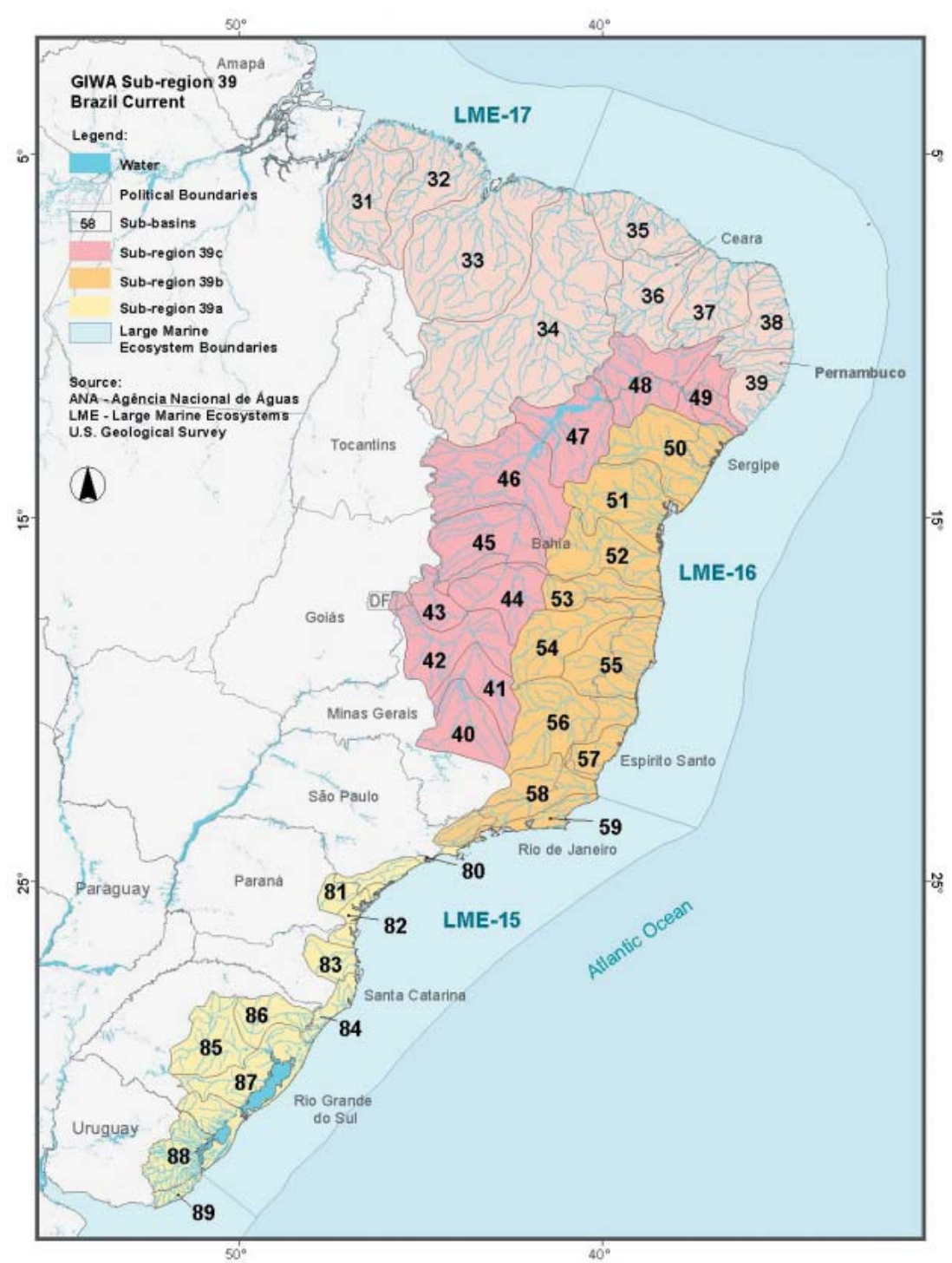


than one Brazilian state and 3 associated Large Marine Ecosystems (2) form these subregions.

Brazil has $2 / 3$ of its 170 million inhabitants living no more than $100 \mathrm{~km}$ from the coast (1). Littoralization-the process of urbanization in which population and economic activities are concentrated particularly along the coast (3) has been one of the main processes responsible for the modification of habitat and communities, as well as increasing pressures on water resources.

The impact assessment protocol of GIWA considered 5 environmental concerns: $i$ ) Freshwater shortage; ii) Pollution; iii) Habitat and community modification; iv) Overexploitation of fisheries; and v) Global change. Habitat and community modification and pollution were considered the priorities in these catchment basins $(4,5)$. Habitat and community modification is divided in 2 main environmental issues (6): i) Loss of ecosystems or ecotones defined as the complete destruction of aquatic habitats over the last 2-3 decades; and ii) Modification of ecosystems or ecotones, including community structure and/or species composition defined as the modification of habitats in terms of extinction of native species, occurrence of introduced species and changes in ecosystem function and services over the last 2-3 decades.

The assessment was meant to address continental waters, coastal/marine waters and their associated living resources. The set list of habitats included: i) freshwater habitats (wetlands, open/running waters and standing waters); and ii) marine habitats (coastal margin ecotones, other benthic marine habitats and pelagic habitats). Additionally, deterioration of some major terrestrial biomes was assessed when associated to changes in the hydrological cycle, desertification and loss of aquatic biodiversity at a subregional scale.

The criteria applied to define the impacts as severe regarding modification of ecosystems and ecotones were (6): i) evidence of change in species complement due to species extinction or introduction; ii) evidence of change in population structure or change in functional group composition or structure; iii) evidence of change in ecosystem services. Regarding loss of ecosystems and ecotones, the criterion applied to score the impacts as severe were: $i v)$ permanent destruction of at least one habitat such as reduction of its surface area by up to $30 \%$ during the last 2-3 decades.

This paper presents the physical and socioeconomic description; the impacts on aquatic habitats and communities, and the main sectorial and root causes for habitat and communities modifications in catchment basins and the associated Brazilian coastal zone to the Atlantic Ocean. Suggestions to design more effective policies for aquatic habitat and community protection are included.

\section{THE PHYSICAL DIMENSION}

\section{São Francisco River Basin, East and South/Southeast Atlantic Basins}

The South/Southeast and East Atlantic basins and São Francisco River basin are associated to the oceanic Brazil Current that gives the name to the subregion. It is a tropical/subtropical ocean margin, a passive continental shelf and moderate continental runoff $(7,8)$. It extends along the Brazilian coast from the São Francisco River delta in the northeast, to Chui in the south of Brazil (Fig. 1). The shelf has a diverse geomorphological configuration, with eminent differences between the East and the South/Southeast
Atlantic basins $(9,10)$. Its length is $4150 \mathrm{~km}$ or $58 \%$ of the Brazilian coastline. The total catchment area is $1.403 \times 10^{6}$ $\mathrm{km}^{2}$ in Brazil and $0.033 \times 10^{6} \mathrm{~km}^{2}$ in Uruguay. 3 major, physical and economical sectors are identified: $i)$ the South/Southeast Atlantic basins (basins 80-89 in Fig. 1) with $0.224 \times 10^{6} \mathrm{~km}^{2}$; ii) the East Atlantic basins (basins 50-59 in Fig. 1) with $0.545 \times 10^{6} \mathrm{~km}^{2}$; and iii) the São Francisco River basin (sub-basins 40-49 in Fig. 1) with $0.634 \times 10^{6} \mathrm{~km}^{2}$. It encompasses partially or entirely 12 Brazilian States and 5 Uruguayan departamentos (Uruguayan political units).

Climate: In the classification of Köppen, the coastal zone associated to these basins is divided into 4 climatic regimes (11). As (tropical humid with winter rainfall) characterizes the northern stretch from the São Francisco River delta to Todos os Santos Bay; Af (tropical humid with frequent rainfall) its central sector, along the south of the state of Bahia; $A w$ (tropical humid with wet summers) governs both the southern sector of East basins and the northern sector of South/Southeast basins; $C f a$ (temperate humid and warm summers) in the remainder and largest part of South/Southeast basins. Precipitation varies between 1000-1500 mm, except for some sectors of Rio de Janeiro and São Paulo states $(A w)$ with 1500 to $2000 \mathrm{~mm}$ and the coast of the Bahia state with 1850 to $2400 \mathrm{~mm}$ (Af) (11). In contrast to the coast, the hinterland of the northern portion of East Atlantic basins and of the lower portion of the São Francisco River is tropical dry with semiarid conditions (Köppen Type Bsh). The middle and upper reaches of the remainder of the East Atlantic basins has Köppen type $A w$ climate (11).

The plankton communities: The Large Marine Ecosystem LME 15 (Fig. 1) is considered a Class II, moderately high productivity ecosystem $\left(150-300 \mathrm{gC} \mathrm{m}^{-2} \mathrm{yr}^{-1}\right)$ (2). Productivity decreases towards the north. LME 16 is considered a Class III, low productive ecosystem $\left(<150 \mathrm{gC} \mathrm{m}^{-2} \mathrm{yr}^{-1}\right)(2)$. However, LME 16 has a more diverse food web than the LMEs to the north 17 and to the south 15 . The foodweb with a high diversity in herbivorous fish is in sharp contrast to the LME 15, where diversity is low at the herbivorous level with only 3 species: sardine (Sardinella brasiliensis), anchovy (Engraulis anchoita) and Maurolicus spp. (12).

Water availability: In most of the East and Southeast/South Atlantic basins, the freshwater shortage concern is raised as a consequence of the littoralization, unplanned land occupation, population and economic growth, increasing demands and raising conflicts, aggravated by pollution, which limits the potential uses of water (13).

On the other hand, in the semiarid portion of São Francisco River basin and Upper East Atlantic, low precipitation, high evaporation, uneven rainfall distribution throughout the year and in multi-annual periods are the main limiting factors (13). According to the water availability indicator mean discharge per capita $\left(\mathrm{m}^{3} \mathrm{yr}^{-1}\right.$ inhab $\left.\mathrm{b}^{-1}\right)$, this subregion encompasses areas that fit in 3 categories (13): Rich (10 000$100000 \mathrm{~m}^{3} \mathrm{yr}^{-1}$ inhab ${ }^{-1}$ ), Sufficient (2000-10 $000 \mathrm{~m}^{3} \mathrm{yr}^{-1}$ inhab ${ }^{-1}$ ) and Regular (1000-2000 $\mathrm{m}^{3} \mathrm{yr}^{-1}$ inhab $\left.^{-1}\right)$. There are only 2 exceptions that fall below these categories. Rio de Janeiro littoral basins (overpopulated basins 59 in Fig. 1). classified as Poor (500-1000 $\mathrm{m}^{3} \mathrm{yr}^{-1}$ inhab $\left.^{-1}\right)$ and, the Upper East Atlantic basins (part of the semiarid of Sergipe and Bahia states $50-51$ in Fig. 1), classified as Very poor (less than $500 \mathrm{~m}^{3} \mathrm{yr}^{-1}$ inhab ${ }^{-1}$ ). 


\section{Western and Eastern Northeast Atlantic Basins and} Parnaíba River Basin

This subregion has a total area of $996000 \mathrm{~km}^{2}$ and an annual average flow $6800 \mathrm{~m}^{3} \mathrm{~s}^{-1}$ (14). It encompasses 3 main hydrographical areas: Western Northeast Atlantic basins (basins 31-33 in Fig. 1); Parnaíba River basin (basin 34 in Fig. 1) and; Eastern Northeast Atlantic basins (basins 35-39 in Fig. 1). Due to significant physical, biological and socioeconomic differences, these 3 hydrographical sectors are here addressed separately.

\section{Western Northeast Atlantic basins}

The Western Northeast Atlantic basins comprise the state of Maranhão and part of the state of Pará. It has an area of $256098 \mathrm{~km}^{2}$, equivalent to $3 \%$ of the total Brazilian territory (14). The hydrographic sector comprises several ecosystems, of which the most important are the equatorial rainforest, mangrove forests, transitional vegetation and deciduous seasonal forest.

Climate: The climate and the temperature in the subregion are characterized as rainy and megathermic - hot and humid, with little or no humidity restrictions for the vegetation. The average temperature of $27^{\circ} \mathrm{C}$ has a narrow annual thermal amplitude $\left(22-32^{\circ} \mathrm{C}\right)$ characteristic of intertropical regions (13). The areas of savannah are suitable for agriculture due to stable temperatures, absence of frost, abundant and evenly distributed rainfall. The average annual rainfall is $1726 \mathrm{~mm}$ with higher precipitation in the transition zone between the savannah and the Amazon rainforest. The average evaporation is also high: $1517 \mathrm{~mm} \mathrm{yr}^{-1}(14)$.

Water availability: The Western Northeast Atlantic basins have a mean discharge rate of $1695 \mathrm{~m}^{3} \mathrm{~s}^{-1}$. The specific discharge rates vary from 5.2 to $9.9 \mathrm{~L} \mathrm{~s}^{-1} \mathrm{~km}^{-2}$ (14). In terms of groundwater resources, the Maranhão Sedimentary Basin is characterized by alternating geological formations with a varied lithological composition comprising arenite, siltstone, claystone and foliolite. The total water demand is $19.4 \mathrm{~m}^{3} \mathrm{~s}^{-1}$ (13). The rivers in the Maranhão Lowlands are important in terms of navigability. Regarding critical hydrological events in the region, there are occasional floods in some sub-basins. Differently from the rest of the Northeast Atlantic basins and part of São Francisco River basin, droughts do not have significant impacts in the Western Northeast (14).

\section{Parnaíba River basin}

The River Parnaíba (basin 34 in Fig. 1) forms the most important and the largest basin in the subregion. It occupies $344248 \mathrm{~km}^{2}$ (4\% of the national territory) and drains the states of Piauí (99\%), Maranhão (19\%) and Ceará (10\%) (14). It is approximately $1400 \mathrm{~km}$ long and most of its tributaries downstream from Teresina city are perennial watercourses supplied by underground pluvial sources. This characteristic, associated with the type of geomorphologic formation, results in the formation of humid valleys of great economic potential. However, due to the acidity and saturation of aluminum present in the soil, it is necessary to treat it with lime prior to agricultural use. More than $90 \%$ of the Parnaíba basin is formed by sedimentary basins with great aquiferous potential. They are porous aquifers and are characterized by their good and consistent porosity and permeability (14). The delta of the river forms an impressive landscape of high potential for tourism.

Climate: According to the Köppen climatic classification, 2 climate types exist in the basin (11): $A w^{\prime}$ - Tropical humid with wet autumn and summers variety, with temperatures relatively lower in March or April occurring in the coastal and Lower Parnaíba region and the semiarid and; BShTropical dry semiarid winter rainfall, characterized by consistent high temperatures above $18^{\circ} \mathrm{C}$, unevenly distributed, with low average annual rainfall found in the hyper-xerophytic drought areas of northeastern Brazil (11). A variant of the $A w$ climate type, namely the $B S w h$ is of the semiarid variety, with a short rainy season in the summer and it affects the southeast section of the basin. The region has an average annual temperature of $27^{\circ} \mathrm{C}$, rainfall of $1726 \mathrm{~mm} \mathrm{yr}^{-1}$ and evapotranspiration of $1517 \mathrm{~mm} \mathrm{yr}^{-1}$. The lowest relative humidity readings $(57 \%)$ and some of the highest evaporation values $\left(3000 \mathrm{~mm} \mathrm{yr}^{-1}\right)$ are to be found at the source of the River Parnaíba.

Water availability: The average discharge rate of the River Parnaiba is $1272 \mathrm{~m}^{3} \mathrm{~s}^{-1}(14)$. Water availability for the region stands at $11306 \mathrm{~m}^{3}$ inhab ${ }^{-1} \mathrm{yr}^{-1}$, which corresponds to $40 \%$ of the national average (28 $\left.198 \mathrm{~m}^{3} \mathrm{inhab}^{-1} \mathrm{yr}^{-1}\right)$. A significant aspect is the basin's specific rate of discharge $\left(3.7 \mathrm{~L} \mathrm{~s}^{-1} \mathrm{~km}^{-2}\right)$, well below the national average of $\left(133 \mathrm{~L} \mathrm{~s}^{-1} \mathrm{~km}^{-2}\right)$. The explanation for this is the uneven distribution of the basin's surface water resources, as the majority of the tributaries on the right bank of the Parnaíba are temporary (14). Regarding groundwater, the region is privileged in comparison with the other basins in the Brazilian northeast. Maranhão aquifer (550 $000 \mathrm{~km}^{2}$ in area) is predominantly situated in the Parnaíba basin whose reserves $\left(13 \times 109 \mathrm{~m}^{3} \mathrm{yr}^{-1}\right)$ correspond to $85 \%$ of the current demand of the whole northeastern region. However, the prospecting capacity is $977 \times 10^{6} \mathrm{~m}^{3}$, $10.8 \%$ of the potential supply (14).

\section{Eastern Northeast Atlantic basins}

The Eastern Northeast has an area of $287348 \mathrm{~km}^{2}$ (3\% of the Brazilian territory) and includes several small coastal basins where short extension and flow are found. The long period average flow is $813.2 \mathrm{~m}^{3} \mathrm{~s}^{-1}(14)$. This area includes fragments of the following biomes: Atlantic forest, caatinga, small areas of cerrados and coastal and insular biomes. In this area, one of the most severe impacts due to anthropogenic pressures on the native vegetation is observed: the caatinga was devastated and replaced by pasture; the original forest in the Zona da Mata (Atlantic rainforest) was replaced by the sugarcane plantation. Logging is, however, still one of the main impacts observed (15).

Climate: As a consequence of the intense solar radiation, the annual average temperature is high $\left(24.5^{\circ} \mathrm{C}\right)$ and the annual thermal variation is low $\left(2^{\circ}\right.$ to $\left.5^{\circ} \mathrm{C}\right)$, a common characteristic of intertropical regions (14). The littoral from Ceará state to Alagoas state (basins 35-39 in Fig. 1), shows an annual average precipitation of $2700 \mathrm{~mm}$, but the precipitation goes down to less than $400 \mathrm{~mm}$ in the inner part of Paraíba state (14). The littoral from Ceará to Alagoas has an extremely high evapotranspiration, which results in great losses for the reservoirs, with values that reach $3000 \mathrm{~mm} \mathrm{yr}^{-1}$ in Pernambuco, Rio Grande do Norte and Ceará states (14). The critical hydrological events are: flooding, which are more important in big cities and, long drought periods.

Water availability: The Eastern Northeast Atlantic basins present an average flow of $813 \mathrm{~m}^{3} \mathrm{~s}^{-1}$ and the minimum flow is $38.15 \mathrm{~m}^{3} \mathrm{~s}^{-1}(14)$. It is estimated that the availability of water corresponds to $30 \%$ of the average flow or $244 \mathrm{~m}^{3} \mathrm{~s}^{-1}$. 
The coastal basins from Ceará to Alagoas state present a high diversity of rivers, streams, most of them of intermittent nature (13). Regarding groundwater resources, metamorphic and ignean rocks with a thin cover of intemperism, 3-5 m thick, predominate, creating fractured aquifers $(75 \%$ of the whole area). High salt content in the groundwater is frequent, making difficult its use for drinking, irrigation, and industrial purposes. During the last decade, desalinization of the groundwater has been increasing (14). However, unsustainable exploitation of these aquifers has led to more than $70 \%$ of wells in precarious conditions being, abandoned. In many areas, groundwater is the only available option to supply cities in the semiarid northeast.

\section{THE SOCIOECONOMIC DIMENSION}

\section{São Francisco River Basin, East and South/Southeast Atlantic Basins}

The South/Southeast Atlantic basins host 6.81 million inhabitants and the East Atlantic basins, 37.67 million inhabitants (16). The basins of Rio de Janeiro state littoral (basins 59 in Fig. 1) are the most densely populated basins, with 11.2 million inhabitants in total.

The São Francisco River basin has about 13.95 million inhabitants (16), $26.4 \%$ of them live in $1 \%$ of the drainage area, corresponding to the Belo Horizonte metropolitan area in Minas Gerais state (13). Except for Rio de Janeiro and Paraná states that presented the highest population growth rate, in the rest of the subregion this indicator was reduced to 1.09 to $2.01 \%$ a year for the period $1991-2000$ (16). Rural populations decreased during the period 1991-2000, a trend observed previously (1980-1991) where $67 \%$ to $96 \%$ of the population lives in urban areas (16). The average GDP per capita varies from $>3779$ USD in the states of Rio Grande do Sul, São Paulo, Rio de Janeiro, down to 1619 USD in the northeast portion (Upper East Atlantic basins and Middle/Lower São Francisco) (13).

Sanitation: Brazil has $81.5 \%$ of the population connected to the water supply system (13). In the subregion, the population with water supply varies from $81.9 \%$ (Bahia state) to $96.4 \%$ (Paraná state). Regarding sewerage systems, only 4 states (Minas Gerais, Espírito Santo, Rio de Janeiro, and São Paulo) present higher values of population connected (58.6\% to $86.6 \%$ ) than the national average of $47.2 \%$ (13). For sewage treatment, the figures are worse: only Rio de Janeiro and São Paulo states have a higher percentage of treatment $(32.2 \%$ and $32.5 \%$, respectively) than the national average of $17.8 \%$ (13). This is the result of insufficient public investments, unclear rules for the private sector participation and spots of poverty found in the most economically developed states (17).

\section{Western Northeast and Eastern Northeast Atlantic Basins and Parnaíba River Basin}

The population in this subregion is 13.5 million inhabitants (16), most of them living on the coastal area. Large extensions of the subregion are marked by a stagnant economy, high poverty levels, low population growth and a large rural population $(37 \%)$ against the national average of $18 \%$. The average density is 10 inhab. $\mathrm{km}^{-2}$ (14), although Pernambuco has the largest coastal population density in the country $(>804$ inhab $\mathrm{km}^{-2}$ ) (18). At least $60 \%$ of the economically active population is involved in the informal sector of the economy (14). In 1999, the Gross Domestic Product (GDP) per capita, according to ANA (14) was below USD 1619, when the national average was USD 3102 . The basic sanitation indicators show severe deficiency in comparison with the national level (Table 1).

\section{ENVIRONMENTAL IMPACTS}

\section{Impacts on Biomes Important for the Integrity of the Aquatic Systems}

The original landscape of Brazil included $61 \%$ of dense humid forests (47\% Amazon forest and 14\% Atlantic forest); the other $37 \%$ of the territory was formed by open dryer forests ( $24 \%$ cerrado and $13 \%$ caatinga). There are penetration and transition zones between 2 or more of these biomes (19). The main terrestrial biomes of importance for the integrity of the aquatic systems in the basins described above and their associated coastal zones, are presented below.

The caatinga is the prevalent biome of the semiarid region in northeastern Brazil and the São Francisco River basin, characterized by uneven distribution of the rainfall in time and space. It covers around $736836 \mathrm{~km}^{2}, 0.8 \%$ of which is protected. Formed by small trees, the caatinga is usually covered with thorns adapted to poor and dry soils. From 1984 to 1990, the caatinga was reduced from $1009915 \mathrm{~km}^{2}$ to $727695 \mathrm{~km}^{2}$, a loss of $28 \%$ in only 6 years $(20)$.

Cerrado is the regional name for savannah. It is the second largest Brazilian biome, after the Amazon forest, with $1967768 \mathrm{~km}^{2}, 0.8 \%$ now being protected. About 85\% of the plateau which occupies the midwest of Brazil was originally dominated by the cerrado, representing around $1.5-2.0 \times 106 \mathrm{~km}^{-2}$, or $20 \%$ of the country's surface. The vegetation of the cerrado is a combination of grasslands and bushes, with sparse small tortuous trees. Only 35\% of the native vegetation shows no signs of anthropogenic interference (21). Most of the cerrado original area was transformed into agriculture, livestock, urban development and exploitation of wood biomass for charcoal production. Together with caatinga, cerrado is one of the exclusively Brazilian biomes. Inappropriate land uses associated with climate conditions have provoked desertification (Box 1).

The Atlantic rain forest is the second most endangered ecosystem in the world, after the almost extinct forest of 


\section{Box 1. \\ Desertification process}

Desertification in Brazil causes loss of biodiversity and compromises the availability of water resources (22). According to the United Nations Convention to Combat Desertification (23), areas susceptible to desertification in Brazil are mostly located in the semiarid region and this problem is aggravated by the continuous loss of vegetation. A large part of the Eastern Northeast Atlantic, Parnaíba River, and the Middle-Lower São Francisco River basins form the drought polygon that includes 1348 municipalities and 27675908 inhabitants $61 \%$ being located in urban areas (24). However, the drought polygon does not correspond only to the semiarid zone; it also includes areas with positive annual water balance and is characterized by high environmental and social vulnerability, since they are among the poorest in the country (25). Four desertification spots comprising a total of $18743.5 \mathrm{~km}^{2}$ are found in the states of Piaui Ceará, Rio Grande do Norte and Pernambuco. In $10 \%$ of the semiarid region $\left(98595 \mathrm{~km}^{2}\right)$, the stage of desertification is considered very severe; in $8 \%\left(81870 \mathrm{~km}^{2}\right)$ it is considered severe and; in $393897 \mathrm{~km}^{2}$ it is considered moderate (26). According to the Ministry of Environment, Water Resources and Legal Amazon MMA, the status of desertification in the semiarid region can be qualified as very severe on $98595 \mathrm{~km}^{2}$, and severe on $81870 \mathrm{~km}^{2}$ $(10 \%$ and $8.5 \%$ of the semiarid, respectively). Paraíba and Ceará are the Brazilian states most affected by desertification, $63 \%$ and $52 \%$ of their total surface, respectively (27). Environmental impacts due to desertification comprise: i) destruction of terrestrial and associated to aquatic system habitats; ii) significant reduction in the availability of water resources (silting of rivers and reservoirs); and iii) significant changes in the physical and chemical properties of the soil. These impacts include losses in the productive capacity, causing social changes, such as migrations, which disarrange families and cause severe impacts on urban centers $(15,28)$.

Madagascar. About 5 centuries ago, when Brazil was colonized by Portugal, the Atlantic rainforest covered 15\% (1.29 x $10^{6} \mathrm{~km}^{2}$ ) of the country (29). Originally this biome was spread along the whole South American coast, following the Atlantic Ocean but the colonization replaced it almost completely by sugar cane and coffee plantations. Only 7.3\% (94 $000 \mathrm{~km}^{2}$ ) of the original forest remains (29) and $0.7 \%$ is protected by law. During 1990-1995, the deforestation rate of the Atlantic forest was 2.5 times the deforestation rate observed in the Amazon forest (29). The removal of the Atlantic rainforest may have severely damaged the surface water resources. The most important remaining fragments of the forest are currently found along the southern granitic sector of the Southeast Atlantic basins, along stretches of the steep relief coastal mountain range of Santa Catarina, Paraná, São Paulo, and Rio de Janeiro states.

Araucaria forests of southern Brazil (coniferous forests) exists in small sections in high altitudes (above 600-800 m) of southern Brazil, and have been impacted by intense human activities, mainly as a result of the timber trade at the start of the last century.

Savannah (pampas) is found in southern Brazil and northern Uruguay (South Atlantic basins) where the climate is temperate. The open lands of the plains and plateaus rolling hills are colonized by field pioneering species of grass that form a vegetation type of open savannah. There are areas of seasonal forests and of fields of grass-woody covering. This biome represents $2.4 \%$ of the Brazilian biomes, with 171386 $\mathrm{km}^{2}$, and only $0.3 \%$ is protected. The pampas occur mainly in the high areas of the south of Rio Grande do Sul state and have been greatly altered by forest fires, cattle raising, and crop plantation (30).

\section{Coastal and Marine Ecosystems}

The coastal and marine ecosystems in Brazil are generally associated with the Atlantic rainforest and its ecotones, most of which are dependent on the forest which extends down to the coastline, for freshwater, sediments and nutrients supply.

\section{Salt marshes (marismas) and lagoons}

Further south from Santa Catarina state (South Atlantic basins), the temperate climate disfavors the mangrove forests and the wetlands become dominated by seagrasses. These salt-marshes are termed marismas. They also cover the borders of estuaries and support the adjacent coastal waters with nutrients and biological production (31). This ecosystem extends into Uruguay. Dunes which run parallel to the shoreline are formed by windborne deposits of sandy quartz material. Approximately $2.5 \%$ of salt marshes are inside Conservation Units, sush as the Taim and the Lagoa do Peixe National Park, state of Rio Grande do Sul. Patos, the largest lagoon $\left(10360 \mathrm{~km}^{2}\right)$ is severely impacted by pollution resulting from drainage for rice culture, discharge of untreated sewage, plus fishing of shrimp (Penaeus sp.) and mullet (Mugil sp.) during the spawning season, hunting, and civil construction $(32,33)$. In Patos Lagoon estuary, $10 \%$ of marsh land was lost over the last 40 years and the annual rate of loss of marsh area in this estuary is $0.25 \%$ (34). The Mirim Lagoon (Merin in Spanish) (basin 88, Fig. 1) shared by Uruguay and Brazil, is affected by the use of pesticides in the rice plantations (35).

\section{Restingas, sand dunes and beaches}

The word restinga is used to describe a type of geological feature of the littoral or, in the ecological and botanical senses, to describe a certain arbustive assemblage typical of the Brazilian meridional and northern coasts (36). This vegetation accompanies beaches and sand dunes. They can be easily disturbed by human occupation since the substrate is mobile and needs to continuously accommodate with the wind and water flows. In the states of Ceará, Piauí, and Maranhão, most of the coastline runs parallel to Ecuador where constant strong winds drive immense amounts of sands to the coast, creating large dune fields, which continuously change the coastal geomorphology (37). Restingas and sand-dune fields have been removed for cultivation of cashew, coconut trees or to give place to residential areas and coastal roads. The removal of the vegetation close to dunes can alter the groundwater level and increase the movement of the dunes (37). 
Rocky shores, coastal and oceanic islands

Rocky shores have suffered severe impacts, the main pressures being on the existing biological diversity; a consequence of overexploitation of species, introduction of exotic species, civil construction and pollution. The oceanic islands in northeastern Brazil contribute to the marine biodiversity and fisheries abundance of the region and they house important endemic species. Due to the large distance (thousands of kilometers) from the coast, most of them remain intact: Parcel de Manoel Luiz, Atol das Rocas and, Arquipélago de São Pedro e São Paulo. However, Arquipélago de Fernando de Noronha, the largest island, with a population of over 2000 people, and a density of 115 inhab $\mathrm{km}^{-2}$ (38) is facing habitat modification with the introduction of exotic species, population growth, tourism, and lack of a sewerage system.

\section{Mangrove forests}

Historically, mangroves have provided protein rich food for the Brazilian coastal population from the sambaqui men (tribes that inhabited the Brazilian coast during the pre-Columbian period more than 7000 years ago), and since then, to the populations who succeeded them. Mangrove forests have been destroyed for: charcoal/timber exploitation; building material; land reclamation for urbanization; installation of evaporation ponds for salt extraction (39). More recently, these activities have withdrawn to give place to shrimp farming and building roads, marinas, and hotels. The removal of the vegetation affects the sedimentary stability of the environment. The most characteristic trees are the Rhizophora mangle, the Avicenia schaueriana and the Laguncularia racemosa. They occur from the northern border of the country all the way down to Santa Catarina state. In Brazil, mangrove forests are protected by specific federal and regional laws which are not always enforced (36). Among the species that depend on mangrove ecosystem, there are crab species such as, Ucides cordatus, Callinectes danae and Cardisoma guanhumi; the bivalves, Mytella guyanensis, Macoma constricta, Anamalocardia brasiliana and Crassostrea rhizophorae, which are an important source of income for populations living along the Brazilian coast, and for fish species of importance to commercial fishing Mugil sp., Centropomus sp., Sardinella aurita, Brevoortia tyrannus and the shrimp, Penaeus spp. (36).

East and Southeast Atlantic basins: The mangrove forest along Bahia state littoral (upper part of the East Atlantic basins) presents higher biodiversity than in the rest of the coast. The intensive soil excavation and transport for construction of the Rio-São Paulo highway (located in basins 59 and 81 in Fig. 1), associated with the regional rainfall regime, have caused intensive erosion and a significant increase of suspended solids in coastal waters. Additionally, the sediment transport and sedimentation rates in Sepetiba Bay in Rio de Janeiro state littoral have changed dramatically during the $1950 \mathrm{~s}$, with water-sediment transposition from another basin (River Paraiba do Sul) for the purpose of supplying the metropolitan area of Rio de Janeiro. The sedimentation rate increased from $30 \mathrm{mg} \mathrm{cm}^{-2} \mathrm{yr}^{-1}$ to over $250 \mathrm{mg} \mathrm{cm}^{-2} \mathrm{yr}^{-1}$ (1). The impacts include smothering of benthonic species, interference with the filtering species and fish respiration, biodiversity loss, and reduction of fisheries stocks. Only $50 \%$ of the original mangrove areas remain in the region. In Guanabara Bay, Rio de Janeiro state, mangroves are threatened by the illegal exploitation of mangrove wood for the brick industries in the environmental protection area of Guapimirim and by occupation by low-income populations.

Western, Eastern Atlantic basins and Parnaiba River basin: Only the states of Piauí and Maranhão on the Western Northeast Atlantic basins still possess significant areas of nonimpacted mangrove swamps. It is estimated that the original area of mangrove swamp on the coast has been reduced to $30 \%(15)$. The conversion of the mangrove to shrimp farms happened over a period of less than 10 years, changing drastically the natural and ecological balance of the estuaries. The sector directly affected by mangrove ecosystem losses is artisanal fisheries. Shrimp aquaculture also affects water quality and in the River Parnaíba it is causing crab (Uca sp.) mortality. There evidence of modifications in population structure due to the introduction of exotic species for aquaculture, such as: oysters (Crassostrea gigas), shrimps (Macrobrachium rosenbergii, Litopenaeus vannameii), carps (Cyprinus carpio), tilapia (Oreochromis niloticus) and Amazonian fishes (tambaqui Colossoma macropomum, tucunaré Cichla ocelaris) (40).

\section{Reefs}

In Brazil, the coral reefs are found along $3000 \mathrm{~km}$, from Maranhão state (Western Northeast Atlantic basins) as far as southern Bahia state (East Atlantic basins), making up the only reef systems in the South Atlantic. The main coral species on these reefs occur only in Brazilian waters, where they form structures unparalleled in other regions, and there are major gaps in our knowledge about them (41). The Brazilian reefs are not very diverse in species numbers, but have a high proportion of endemic corals and reef fishes on top of other more cosmopolitan species (41).

The coast of Bahia state (upper part of the East Atlantic basin) has $20 \mathrm{~km}$ of endemic coral reefs. Over the last 15 years, this coastal segment has experienced an acceleration of generally unplanned urbanization, with indiscriminate use of septic tanks in urban centers contaminating the groundwater. In the northern coast of Bahia, high densities of macroalgae and heterotrophic organisms were found impacting coral reefs (42). A model has been proposed (42) with nutrient enrichment via groundwater seepage as the mechanism to explain the eutrophication. Data suggest that the great availability of nutrients is affecting the trophic structure, with the increasing turf and macroalgae growth, reduction of light penetration to the coral colonies, and competition for space, preventing the settlement of new coral larvae (42).

Reefs in the Northeast Atlantic basins are of 3 different types: $i$ ) beach rocks, inorganic precipitations of carbonates, which take place at lines of sea level stability and appear like straight lines along the shore; ii) calcareous algae which build large, porous structures; and iii) corals. All 3 types are important breeding grounds for a number of marine species of economic (lobsters) and environmental value (biodiversity). In the past, coral reefs in this subregion were mined for construction of houses, churches, and military fortifications. Currently, they are vulnerable to increased sedimentation due to unsustainable land use and coastal erosion; chemical pollution from domestic sewage and pesticides from the sugarcane plantations; overfishing; tourism; port and oil/gas terminals development (43). 
Seagrass meadows

Seagrass meadows are usually associated to reefs along the northeastern coast. Its main vegetation is the seagrass Spartina. These meadows are also the main feeding grounds of the Brazilian manatee (Trichechus manatus).

\section{Environmental Impacts Due to Reservoirs/Dams Construction}

The construction of many dams and regularization of stream flows have caused the elimination of rapids, isolation of marginal lagoons and margin niches, sandy bottoms due to the reduction of terrigenous inflows and the disappearance of some species that need currents to reach sexual maturity. São Francisco River is the most conspicuous example (44). Fluvial navigation has been directly affected due to silting up and the formation of large sandbanks.

The Lower São Francisco and its delta (sub-basins 48-49 in Fig. 1), have suffered significant morphological changes due to the reduction in sediments/nutrients transport that has caused sediment deficit in the coast, and erosion and modification in ecological niches $(44,45)$. According to the measurements of biomass of phytoplankton, the trophic status of the pelagic ecosystems was found to be extremely low in the Lower São Francisco, both estuary and contiguous sea, indicating that the river is contributing very little to planktonic production in the coastal zone (44). This seems to be the main cause of the decrease of fish production recorded at the river's mouth after the construction of Xingó reservoir in 1997 (Fig. 2).

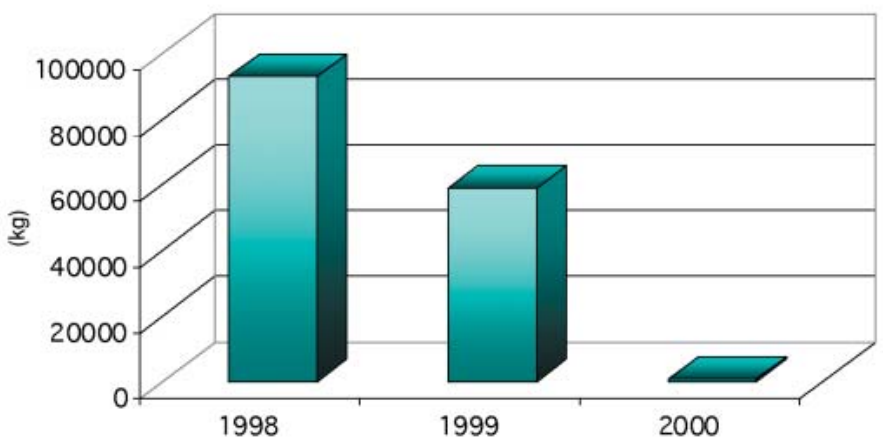

Figure 2. Ichthyofauna productivity $\left(\mathrm{kg} \mathrm{yr}^{-1}\right)$ at the São Francisco River estuary (44).

Damming is also increasing significantly in northeastern Brazil (46), for both power generation and water supply where water resources are scarce (47). At the Jaguaribe River, Ceará State where semiarid conditions make water supply a key issue, construction of large reservoirs and irrigation networks has decreased the sediment transport to the coast, reducing its fertilization potential. The sediment load is $2 \mathrm{x}$ $10^{6}$ tonnes $\mathrm{yr}^{-1}$, with a sediment yield of about 28 tonnes $\mathrm{km}^{-2}$ $\mathrm{yr}^{-1}$, which represents only 10 to $50 \%$ of the necessary continental supply to maintain coastline stability and the integrity of the associated ecosystems (48). The Parnaiba River was dammed in the late 1970 s to form a lake for hydroelectric power generation, marking the end of commercial navigability, and an obstacle for fish migration (15).

\section{Environmental Impacts Affecting the Biodiversity of Freshwater Fishes}

Due to the isolation of the basins during the evolutionary process, a very high degree of endemism is found in the rivers of the Atlantic rainforest. Among 38 sites of freshwater fish endemism identified along the Brazilian coast, 29 are associated to the Atlantic rain forest (49). There are 165 species of fish at risk of extinction in Brazil, according to the list of the Brazilian Institute for the Environment IBAMA (49); 52 species are from rivers in the Atlantic rainforest. In some river sections, discharge of effluents is magnified by the relative low stream flow and impacts are deformities and lesions in Hypostomus affinis and Rhamdia parahybae. In River Doce (basin 56, Fig. 1), the biodiversity of ichthyofauna is currently very low and it is composed of species that show a wide geographical distribution and high tolerance to environmental changes and pollution. These results indicate that significant reduction in the ichthyofauna biodiversity had already occurred before monitoring started (50). The main causes are likely to be increasing turbidity, organic load and reduced oxygen content of the water, and chemical pollution (51).

\section{SOCIOECONOMIC IMPACTS AND CAUSAL CHAIN ANALYSIS}

Economic impacts due to habitat and community modification in the East and South/Southeast Atlantic basins include: loss of revenue from tourism; loss of property value; reduction of fisheries; increased costs for coastal area maintenance due to higher vulnerability to erosion, lower stability of coastline, recovery costs after the occurrence of floods; costs with maintenance and recuperation of river banks; and costs for the control of exotic species (52). Health impacts include major risks for humans from disease caused by habitat alteration, such as proliferation of disease agents and vectors and increased vulnerability to climate changes. Low-income populations are particularly exposed to this kind of impact. Other social and community impacts include: reduced capacity of local populations in meeting basic human needs and migration, for instance, in São Francisco River basin where fish stocks has been drastically reduced; changes in employment opportunities $(52,53)$; loss of aesthetic and recreational values, mostly in the coastal areas where habitat loss has reduced beach use; generational inequity; and loss of natural/cultural heritage (51).

In the Northeast Atlantic basins, particularly in the Brazilian semiarid region, which is the most populated semiarid region in the world, the socioeconomic impact due to habitat and community modification includes: $i$ ) economic losses in agricultural and other losses associated to water scarcity due to desertification; ii) poverty; and iii) huge migratory flows. According to a methodology adopted by the United Nations, the damages caused by desertification amount to USD $250 \mathrm{ha}^{-1}$ in irrigated areas, USD $40 \mathrm{ha}^{-1}$ in rainfed areas and USD $7 \mathrm{ha}^{-1}$ in pasture areas (15). The losses in Brazil due to desertification may add up to USD 800 mill. $\mathrm{yr}^{-1}$ and the cost for recovering the areas is estimated at USD 2 billion over a period of 20 years (15). There are also socioeconomic losses associated with tourism, social welfare, coastal erosion and decreasing fisheries yields. The major health concerns include increasing risk of waterborne diseases, and decrease in availability of drinking water. Respiratory problems associated with airborne sediments occur in populations living in areas in process of desertification in the southeast of Parnaíba River basin (15). Other social and community impacts include loss of traditional sustainable lifestyles. 


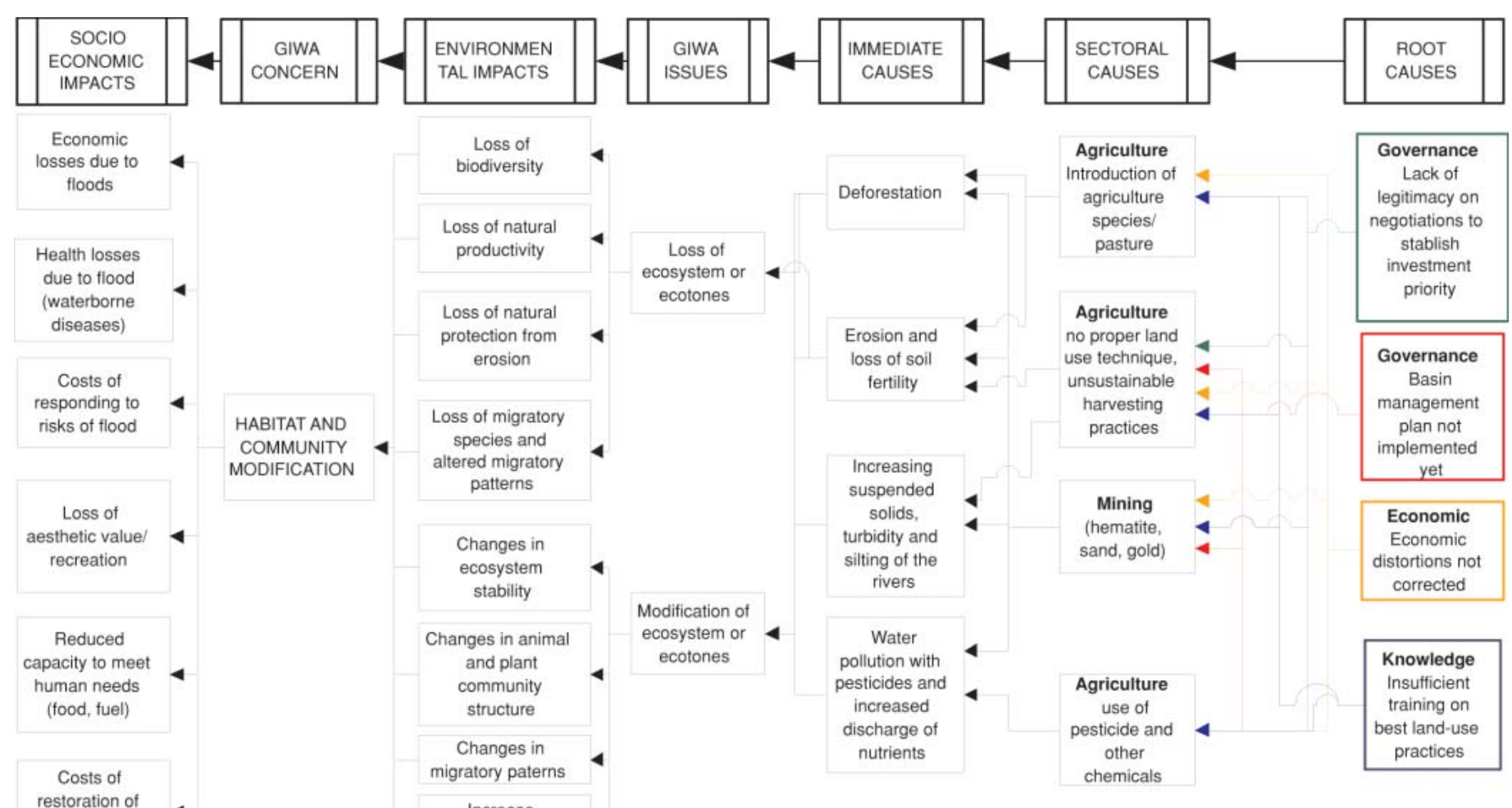

Figure 3. Causal chain analysis for the concern Habitat and Community Modification, Doce River basin, Brazil (17).

\section{Causal Chain Analysis of Habitat and Community Modification}

Drainage basins and densely occupied coastal zones in developing countries are heavily exploited in terms of their natural resources. They meet economic growth at the expense of moderate to severe environmental impacts. This occurs due to a combination of anthropogenic pressure, institutional weakness, poor law enforcement and governance failure, which are often among the root causes of environmental degradation $(17,54)$. The current status of the water resources, coastal zones and their associated living resources in the studied basins fits into the abovementioned scenario. The root causes of habitat and community modification were investigated through a causal chain analysis technique. Figure 3 illustrates the causal chain analysis for one selected aquatic system; Doce River basin (basin 56, Fig. 1), part of the East Atlantic basins. In this basin, mining and agriculture have been the main sectorial causes for erosion, silting and loss or modification of natural habitats. Flooding has caused severe socioeconomic impacts. Some of the most frequent root causes of environmental concerns in the South American region are found in this basin, within the categories of: $i$ ) governance; ii) economic causes; and iii) knowledge (17).

\section{DISCUSSION}

During the last decades, the Brazilian government and several nongovernmental organizations have launched important initiatives to improve water-resources management, and to mitigate increasing losses of biodiversity and habitats. Very seldom do these efforts reflect a coordinated national strategy that integrates land uses, freshwater, associated living resources and coastal management. Historically, water has been seen as a valuable resource that must be managed in order to meet present and future human demands when conflicts and scarcity are expected to increase, particularly in those basins where water demands are higher than availability. In this context, the aquatic environment as such is frequently neglected. Additional problems include: unevenly targeted conservation efforts among and within Brazil's main biomes; limited access to biodiversity information; insufficient participation in government projects by local communities and nongovernmental organizations; and limited publicprivate partnerships. Efforts will be neccessary to address the financial constraints to implementing water biodiversity conservation.

Since the Brazilian National Agency of Waters (ANA) was created in 2000, multiple uses have gained the ruling position in strategic planning. Water-resource plans are being prepared using the watershed as the basic management unit. Recent policies also indicate a trend towards more efficient sanitation systems. Regarding integrated coastal management, the Brazilian Government became involved in coastal preservation and management already in the 1970s when degradation of ecosystems increased due to industrialization and urban growth. Coastal management is supported by the Federal Constitution in Brazil, which defined the coastal zone as national property. The National Plan of Coastal Management PNGC (Law 7661, 1998) and the National Program of Coastal Management (18) encompasses all of 17 coastal states and their municipalities, along the Brazilian Atlantic coast. So far, effective integration between the water resources and the coastal management policies has not been achieved.

The Bi-national Commission Brazil and Uruguay, which had been set up during the 1960 s to perform joint initiatives in the Mirim Lagoon, with Brazilian and Uruguayan agents, acted satisfactorily to address the problems and issues inherent in the proposal of regional development. However, 
attempts at integrated institutional actions were frustrated, and over the years, each country has established its own agenda. Recently, a unilateral legal instrument to help reactivate the Commission was signed (Act No 4258, June, 2002).

The following actions are proposed to protect the water environment and the associated living resources in the studied basins.

- Develop basin programs for sustainable use of the soil and erosion control, with the aim of preserving springs, preventing the silting up of rivers.

- Promote institutional strength and the decentralization of the water-resources management with focus on integrated freshwater-coastal management and protection of the associated living resources.

- Expand both domestic and industrial sewerage and treatment systems, particularly in those coastal cities with high population density.

- Guarantee that aquatic fauna is not adversely affected owing to obstruction of the river course; provide fish passes or such other hydraulic devices for facilitating the free movement or breed the affected fish in captivity; repopulate the river by restocking the upper stretches.

- Implement a sustainable monitoring program with indicators tailored to the subregional conditions.

The following are specific actions proposed to recover/ preserve aquatic habitats and communities.

- Western Northeast Atlantic basins: Establish practices that minimize the threat of deforestation and its subsequent impact on water and associated living resources.

- Parnaíba River basin: Define a strategy for making feasible the use of the high level of groundwater potential, in the semiarid region that does not compromise the ecosystems.

- Eastern Northeast Atlantic basins: Optimize the use of water in irrigation and industry, reduce the losses in the supply system, in order to guarantee the environmental uses.

- São Francisco River basin: Operate the new reservoirs, keeping full discharge rate during some weeks per year, in order to reproduce the natural flooding, which was suppressed by the cascade of reservoirs.

- East Atlantic basins: Implement sustainable uses of land, recover degraded areas; set up effective strategy for prevention of catastrophic floods.

- South/Southeast Atlantic basins: Promote adequate agriculture and irrigation practices; recover areas degraded by mining; create the bi-national Mirim Lagoon Basin Committee to empower the Brazilian and the Uruguayan Mirim Lagoon Agencies; seek innovative solutions to preserve the wetlands.

\section{CONCLUSIONS}

Modification and loss of ecosystems and ecotones are among the issues identified as severe impacts in most of the South American subregions assessed by the GIWA project $(15,17,55,56)$. It has been observed that common root and sectorial causes responsible for modification/loss of ecosystems and pollution allow the development of integrated policy options that address both concerns (17). Although economically expensive and time-consuming, it is technically possible to restore small patches of some aquatic habitats, but not large extensions. The return of the fauna is possible if ecological corridors or hydraulic connections exist. However, no progress regarding aquatic habitat preservation is expected, unless planning and sustainable use of land is taken as a priority by the policy makers. In the long term, habitat and community modification can be mitigated by increasing investments in education. In a short-medium term perspective, compliance cannot be exclusively based on the traditional command-and-control approach that has proved to be too expensive for large geographical areas, particularly in developing countries. New and creative strategies to promote integrated environment management must be developed. Otherwise, it is likely that as habitats are increasingly modified and resources are correspondingly scarcer, the socioeconomic conflicts and ecosystem losses will be aggravated.

\section{References and Notes}

1. Lacerda, L.D., Kremer, H.H., Kjerfve, B., Salomons, W., Crossland, J.I.M. and Crossland, C.J. 2002. South American Basins: LOICZ Global Change Assessment and
Synthesis of River Catchment-Coastal Sea Interaction and Human Dimenson. LOICZ
Reports and Studies No 21, ISBN $1383-4304$.

2. Large Marine Ecosystems of the World 2003. (www.edc.uri.edu/lme/clickable-map.htm) March 2003

3. Masala, C. 1999. Demographic pressure and ecological restraints: The case of the Mediterranean. In: International Security Challenges in a Changing World. Spillmann, K.R. and Krause, J. (eds). ISBN 3-906763-68-4. 349pp.

4. Mayorga, M.I.O., Teixeira, A., Pinheiro, P.R.C., Folhes, M.T. and Melo, C.S. 2002 Brazilian Northeast Scaling and Scoping Report. Global International Waters Assessment GIWA UNEP/GEF. 69 pp.

Marques, M. 2001. Brazil Current: Scaling and Scoping Report. Global International Waters Assessment GIWA UNEP/GEF. 185 p

6. Global International Waters Assessment 2001. GIWA Methodology, Stage I. Scaling and Scoping Guidance to the Methodology and Its Use. Global International Waters Assessment GIWA UNEP/GEF. 92 pp.

7. Walsh, J.J. 1988. On the Nature of Continental Shelves. San Diego, Academic Press Inc, $520 \mathrm{pp}$.

Ekau, W. and Knoppers, B.A. 1999. An introduction to the pelagic system of the East and Northeast Brazilian shelf. Arch. Fish. Mar. Res. 47, 113-132.

Martins, L.R. and Coutinho, P.N. 1981. The Brazilian continental margin. Earth Sci. Rev. 17, 87-107.

0. Knoppers, B.A., Figueiredo, A.G. and Ekau, W. 1999. The coast and shelf of east and northeast Brazil and material transport. Geo-Marine Letters 19, 171-178.

11. Nimer, E. 1972. Climatologia da região Nordeste do Brasil. Rev. Brasil. Geogr. 34, 3-51. (In Portugese).

12. Matsuura, personal communication

13. Agência Nacional de Águas ANA, 2003. Plano Nacional de Recursos Hídricos. Secretaria Nacional de Recursos Hídricos SNRH. Ver. 01. Abril/2003. www.ana.gov.br . Agência Nacional de Água. 2003. Overview of Hydrographical Regions in Brazil. National Agency of Water ANA. (www.ana.gov.br)

15. Mayorga, M.I.O, Melo, C.S., da Costa, M.F. and Brito, V. 2003. Brazilian Northeast: GIWA Regional Assessment 40a. Global International Waters Assessment GIWA UNEP/GEF. 82 pp.

16. Instituto Brasileiro de Geografia e Estatística 2000. Censo Demográfico 2000: Resultados Preliminares. IBGE, Rio de Janeiro. (In Portugese)

17. Marques, M., Knoppers, B., Lanna, A.E., Abdallah, P.H. and Polette, M. 2003. Brazil Current: GIWA Regional Assessment 39. Global International Waters Assessment. 260 pp.

8. Programa Nacional de Gerenciamento Costeiro 1995. Perfil dos estados litorâneos do (In Portugese).
(Inil: Subsidio à implantação do PNGC. PNMA. Série Gerenciamento Costeiro, 9. 19. Eiten G 1992

Brasileira de Ciências Brazilian vegetation types and their causes. Anais da Academia Brasileira de Ciencias, 64 (Supl.), 35-65. 1993. Mapa da vegetação do Brasil. IBGE.

20. Brazil. 1991. Presidência da República. Comissão Interministerial para a Preparação
da Conferência das Nacões Unidas sobre Meio Ambiente e Desenvolvimento-CIMA. da Conferência das Nações Unidas sobre Meio Ambiente e Desenvolvimento-CIMA.
$O$ Desafio do Desenvolvimento Sustentável. Relatório do Brasil para a Conferência O Desafio do Desenvolvimento Sustentável. Relatório do Brasil para a Conferência
das Naçoes Unidas sobre Meio Ambiente e Desenvolvimento. Brasília. (In Portugese)

21as Nações Unidas sobre Meio Ambiente e Desenvolvimento. Brasília. (In Portugese). Mantovani, J. E. and Pereira, A. 1999. Ações Prioritárias para a Conservação da
Biodiversidade do Cerrado e Pantanal. Brasília: INPE/ Ministério do Meio Ambiente/ Biodiversidade do Cerrado e Pantanal. Brasília: INPE/Ministerio do Meio Ambiente/ Brasilia. $32 \mathrm{pp}$.

22. UNGA Second Committee 1999. Implementation of the United Nations Convention to Combat Desertification in Those Countries Experiencing Serious Drought and/or Desertification, particularly in Africa Statement by the Brazilian. Delegation New York, Item 104, 26 October

23. UNCCD website 2003. United Nations Convention to Combat Desertification. Accessed in May 2003. (www.unccd.int/convention/menu.php)

24. SUDENE 1997. Resolução no 11.135/97. Área Municipal, 1997. FIBGE e Contagem da População, 1996. (In Portugese)

25. Viana, M.O.L. and Rodríguez, M.I.V. 1999. Um índice interdisciplinar de propensão à desertificação (IPD): instrumento de planejamento. Rev. Econ. Nordeste REN jul-set, 3, 264-294. (In Portugese).

26. Programa de Combate à Desertificação 2003. IICA, Grupo ESQUEL, Interamerican Development Bank IDB e Fundo Especial do Governo do Japão. (In Portugese).

27. EMBRAPA 1997. Embrapa Semi-Arido dimensiona degradação nos solos da Paraiba. Empresa Brasileira de Pesquisa Agropecuária. EMBRAPA Agência de Notícias (15/04/97). (In Portugese)

28. Rodriguez, V. 1992. Avaliação do quadro da desertificação no nordeste do Brasil: Diagnóstico e perspectivas. Estudo especial. Teresina: Universidade Federal do Piauí.

29. SOS Mata Atlântica and INPE 2002. Atlas dos Remanescentes Florestais da Mata Atlântica 1995-2000. Situação original (Dominio da Mata Atlantica do Decreto Federal 750/93) e Situação atual. SOS Mata Atlântica e Instituto National de Pesquisas Espaciais, INPE. (In Portugese)

30. WWF 2003. World Wild Foundation in Brazil.

(www.wwf.org.br/english/amazonia/default.htm) 
31. Menegheti, J.O. 1998. Capítulo 11. Lagunas Uruguayas y Sur de Brasil. In: Los Humedales de América Del Sur - Una Agenda para la Conservación de la Biodiversidad y las Politicas de Desarrollo. Wetlands International. (In Portugese).

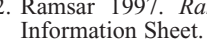

Information. C. 1999. Human populations and cosstel wetands: Conservation and Diegues, A.C. 1999. Human populations and coastal wet.

(1) Cost Subtropical Convergence Environments. The Coast and Sea in the Southwesten lin, pp. 197-203.

. W

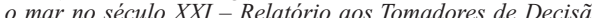
no País. Rio de Janeiro, Comissão Nacional Independente sobre os Oceanos, 408 pp. (In Portugese)

37. Jimenez, J. and Maia, L.P. 1999. Aeolian dune migration, NE Brazil. Sedimentology 46, 689-701.

38. Costa, M.F. and Souza, S.T. 2002. A zona costeira Pernambucana e o caso especial da Praia da Boa Viagem: usos e Conflitos. In: Construção do Saber Urbano Ambiental: a Caminho da Trasdisciplinaridade. Editora Humanidades, Londrina-PR. (In Portugese) Embassy in London. (www srazil.org.uk)

40. Fundacão Centro de Pesquisas Econômicas e Sociais do Piauí. 1996. Macrozoneamento costeiro do Estado do Piauí: Relatório geoambiental e sócio-econômico. Teresina. (In Portugese)

41. Banco de Dados Tropicais 2001. Avaliação e Ações Prioritárias para a Conservação da Biodiversidade da Zona Costeira e Marinha. (www.bdt.org.br)

42. Costa, O.S.Jr., Leão, M.A.N., Nimmo, M. and Atrill, M.J. 2000. Nitrification impacts on coral reefs from northern Bahia, Brazil. Kluwer Academic Publisher. Hydrobiologia $440307-315$

43. Maida, M. and Ferreira, B.P. 1997. Coral reefs of Brazil: An overview. In: Proc. $8^{\text {th }}$ International Coral Reef Symposium, Vol. 1, 263-274.

44. Machmann de Oliveira, A. 2003. Estudo Hidrodinâmico - Sedimentológico do Baixo São Francisco, Estuário e Zona Costeira Adjacente (AL/SE). Relatório Final. Subprojeto 1.1.A UNEP/GEF. 33 pp. (In Portugese)

45. Marques, M., Knoppers, B. Machmann Oliveira, A. 2002. Transboundary basin of São Francisco, Brazil: Environmental impacts and causal chain analysis. Proc. First In Symp. on Transboundary Waters Manag. Monterrey. Associación Mexicana de Hidrologia. pp. 487-494.

46. Petts, G.E. 1990. Regulation of large rivers: problems and possibilities for environmentally sound river development in South America. Interciência 15, 388-395.

47. Kjerfve, B., and Lacerda, L.D. 1993. Mangroves of Brazil. In: Conservation and Sustainable Utilization of Mangrove Forests in Latin America and Africa Regions. Part I: Latin America. Lacerda L.D. (ed.). International Society for Mangrove Ecosystem and the International Tropical Timber Organization.

8. Cavalcante, A.A. 2000. Impactos Ambientais na Região do Baixo Curso do Rio Jaguaribe, CE. MSc thesis. Universidade Estadual do Ceará, Fortaleza. (In Portugese)

9. Ministério do Meio Ambiente 2000. Avaliação e Ações Prioritárias para Conservação da Biodiversidade da Mata Atlântica e Campos Sulinos. Ministério do Meio Ambient MMA, Conservation International do Brasil, SOS Mata Atlântica Foundation, Biodiversitas Foundation, Instituto de Pesquisas Ecológicas, SMASP, SEMAD/Instituto Estadual de Florestas-MG, Brasília. (In Portugese).

0. Barbosa, F.A.R., Souza, E.M.M., Vieira, F., Renault, G.P.C.P., Rocha, L.A., MaiaBarbosa, P.M., Oberdá, S.M. and Mingoti, S.A. 1997. Impactos antrópicos biodiversidade aquatica. Ministerio do Meio Ambiente. Avaliação e Ações

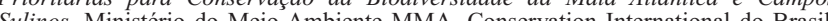

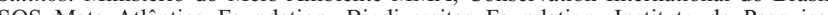
SOS Mata Alânica Foundation, Biodive

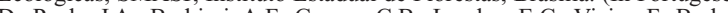

, Barbosa, F.A.R. Costa, H.S.M. Guerra. L.P. Monte-Mór, R.L.M., Simões, R.F. and Braga, T.M. 1997. Costa, H.S.M., Guerra. L.P., Monte-Mor, R.L.M., Simões, R.F. and Braga, T.M. 1997. UFMG/CEDEPLAR-ECMVS, PADCT/CIAMB. Belo Hogizono da Juho (In Pottumese).

52. Marques, M. 2003. S cioccon, . Assessment 39. Global International Was Paraíba do Sul. PGRH-RE-010 RO Vol. 1. COPPE, UFRJ. Rio de Janeiro, Brazil. (In Portugese)

54. Marques, M. 2002 Análise da cadeia causal da degradação dos recursos hídricos: Proposta de modelo conceitual do projeto GIWA UNEP/GEF, $2^{\circ}$ Simpósio de Recursos Hidricos do Centro Oeste SIMPORH, 2002 Campo Grande-MS, CD Rom. (In Portugese)

55. Barthem, R. B, Charvet-Almeida, P., Montag, L.F.A. and Lanna, A.E. 2003. Amazon. GIWA Regional Assessment 40b. Global International Waters Assessment GIWA UNEP/GEF. 68 pp.

56. Calcagno, A., Mugetti, A., Brieva, C., Gonzalez, S., Magnani, C. and Rafaelli, S. 2003. Patagonia Shelf. Regional Assessment 38. Global International Waters Assessment GIWA UNEP/GEF. $200 \mathrm{pp}$

57. The authors want to thank the experts and the institutions that supported the assessment. The financial support of the United Nations Environmental Program UNEP and the Global Environmental Facility GEF to the implementation of the project and to the coordination work in Latin America is also acknowledged.
Marcia Marques is associate professor, Department of Sanitary and Environmental Engineering, Rio de Janeiro State University, Brazil. She has a PhD in chemical engineering from the Royal Institute of Technology, Stockholm, Sweden. She is Coordinator for Latin America and the Caribbean Region, Project GIWA UNEP/GEF. Research in water resources pollution; landfilling, impact assessment. Her address: Department of Sanitary and Environmental Engineering, Rio de Janeiro State University UERJ, Rua São Francisco Xavier, 524, sl 5024 BI E, Maracanã, CEP 20559-900, Rio de Janeiro, Brazil. marcia@marques.pro.br

Monica Ferreira da Costa is associate professor, Department of Oceanography, Federal University of Pernambuco, Recife, Brazil. PhD in environmental sciences from the University of East Anglia, Norfolk, UK. Her research is in chemical-biological interactions in the ocean; interaction between marine organisms and environmental parameters. Her address: Dept of Oceanography, Federal University of Pernambuco UFPE, Av. Arquitetura s/n, CDU, Recife, CEP 50740-550, PE - Brazil. mfc@ufpe.br

Maria Irles de $\mathrm{O}$. Mayorga is associate professor at the Department of Agriculture Economy, Federal University of Ceará, Fortaleza, Brazil. PhD in economy at the University of Arizona, USA. She cooperates with the University of Arizona in research projects at the Brazilian semiarid region. Her address: Department of Agriculture Economy, Federal University of Ceará - UFC, Campus do Pici, Pici, Bloco 826, CEP: 60 451-970, Fortaleza - Ceará, Brazil. irles@ufc.br

Patrícia R. C. Pinheiro is associate professor at the Department of Fisheries Engineering, Federal University of Ceará, Brazil. PhD in biological science at the National Institute of Amazon Research INPA, Manaus, Brazil. Her research is in nutrient cycles; biological oceanography; ecosystem ecology and fisheries. Her address: Department of Fisheries Engineering, Federal University of Ceara, Pici Fortaleza, Ceará, Brazil. pinheiro@ufc.br 